\title{
The Structure of the Mahāyānasūtrālamkēara:
}

From the Interpretation of a Tibetan Commentary

\author{
Matsuda Kuninori
}

\section{Introduction}

The Mahāyānasütrālamkāra (-bhāsya) (MSA) is one of the major treatises of the early Yogācāra School. This treatise consists of many sections and deals with a range of topics, the commentaries of which begin with the phrases like "there are a number of verses concerning something." These sections do not appear to be arranged according to any structure, with the result that the treatise has been said to resemble a patchwork. ${ }^{1)}$

Nonetheless, a number of studies have pointed to some correspondence between the structure of the MSA and that of the Bodhisattvabhümi, the 44 manaskāras found in the Chapter XI, that of the Chapter IX, and so forth. ${ }^{2)}$ These studies suggest that the MSA was written according to a plan of some sort and to have had a multilayered structure. ${ }^{3)}$

In order to elucidate this structure, we need to examine carefully all the related material. Thankfully, many Tibetan commentaries are now widely available as a result of the recent publishing of the $b K a$ 'gdams gsung 'bum.

In this paper, I examine an interpretation of the $M S A$ that appears in one such Tibetan commentary contained in the $b K a$ 'gdams gsung 'bum, namely, that written by rNgog lo tsa' ba Blo ldan shes rab (1059-1109).

\section{Available Tibetan Commentaries}

Before beginning the examination, I would like to survey the Tibetan commentaries of the MSA. Ten or so Tibetan commentaries are known through the catalog of rare texts (Tho yig) written by A khu rin po che, but only a few of them are available. Odani's work (1984), thought to be the most notable study of the Tibetan commentaries on the MSA, also refers to the Tho yig, and makes use of the two commentaries found there and two other commentaries written by $\mathrm{dPal}$ man dkon mohog rgyal mtshan and $\mathrm{Mi}$ pham rin po 
che (pp. 48-84).

In addition to these four works, there are 10 commentaries in the $b \mathrm{Ka}$ ' gdams gsung 'bum. ${ }^{4)}$ The next section will examine one of the commentaries contained in the bKa'gdams gsung 'bum, namely, mDo sde rgyan gyi don bsdud (Don bsdus), written by rNgog lo tsa' ba Blo ldan shes rab. ${ }^{5)}$

There also appears to be another commentary that is a summary of the Don bsdus, mentioned by Kanō $(2007$, p. 118, n. 26). This means there are at least 15 commentaries now available.

\section{Outline of the Don bsdus}

The Don bsdus consists of 23 folios and is composed of three components: beginning verses, a main body, and ending verses. It opens with the line, "The Mahāyānasūtrālamkāra composed of three parts of contents: (1) establishing the occasion (skabs sgrub pa), (2) bringing the joy (spro ba bskyed pa), and (3) explaining the teaching (chos brjod pa)." (Don bsdus $(2009,478.11-12)^{6)}$ ) The MSA is thus divided into three parts. ${ }^{7)}$

The Don bsdus explains the first part, (1) "establishing the occasion," by reference to the first three verses of the MSA. The rough outline of this part is as follows (with locations in Don bsdus (2009)):

1 establishing the occasion

$478.11 \quad$ I, kk. 1-3

1.1 perfection of purpose of the treatise

$478.15 \quad$ I, k. 1

1.1.1 meaning of purpose

1.1.2 meaning of words

1.1.3 summarized meaning

1.2 perfection of subject matter

$482.14 \quad \mathrm{I}, \mathrm{k} .2$

1.2.1 substance of the Mahāyāna

1.2.2 practices to carry out the meaning of the Mahāyāna

1.3 perfection of the meanings of terms $487.10 \quad$ I, k. 3

The first division of this part, (1.1) "perfection of purpose of the treatise" (bstan bcos kyi dgos pa phun sum tshogs pa), explains the purpose of the treatise, relating to I, k. 1 of the $M S A$, through the eight kinds of kāpadeśa. ${ }^{8)}$ In this case "purpose" means why the author is writing the treatise. One of the aspects of this purpose, namely, aspect as a result, is explained four ways: in terms of (a) subject matter (brjod par bya ba, that which is to be re- 
lated), in terms of (b) the purpose ( $g d o s p a)$, in terms of (c) the purpose of the purpose ( $g d o s$ pa'i gdos pa) and in terms of (d) a particular relationship ('brel ba'i khyad par). According to the explanation (Don bsdus $(2009,481.1 \mathrm{ff}$.$) ), these four ways represent, re-$ spectively, efficacy, practicability, necessity, and the absence of any easier approach, and thus they draw the reader into the treatise. ${ }^{9)}$

Division (1.2), "perfection of subject matter" (brjod bya phun sum tshogs pa), presents the subject matter of the treatise, relating to I, k. 2 of the MSA. This will be discussed below.

Division (1.3), "perfection of meanings of terms" (ming gi don phun sum tshogs pa), explains the inclusion of the word "rgyan" in the title, although the explanation is not detailed.

The Don bsdus includes the observation here with reference to the Bodhisattvabhümi that "learning is of three kinds: what to learn, how to learn, and who learns" (Don bsdus (2009: 487.16ff.)).

Next, the Don bsdus discusses the second part of the MSA, (2) "bringing the joy." This part has two divisions, as follows:

2 bringing the joy

2.2

$$
\text { explanation of greatness }
$$

establishment of being the words [of the Buddha]
$490.21 \quad$ I, kk. 4-21

490.22 I, kk. 4-6

$491.1 \quad$ I, kk. 7-21

This part is related to the latter part of Chapter I. Previous studies have often observed that Chapter I in Lévi's edition of the MSA is divided into two parts: the first part, kk. 1-6, plays the role of an introduction for the whole treatise, while the second, kk. 7-21, treats the authenticity of the Mahāyāna. The Don bsdus, by contrast, tends to divide it into the two parts of kk. 1-3 and kk. 4-21. This seems quite reasonable given the perspective of the initial introduction of the whole treatise and its presumed discussions.

Having finished a somewhat detailed explanation of this section, the Don bsdus says, "(The above is) the opportunity for the establishment of the Mahāyāna. The teaching to discriminate the taking of refuge ( saranagamana) is briefly shown as follows...." Hereafter, the Don bsdus begins to annotate the $M S A$ with the concluding sentence, in most cases, of the chapter names or the topic names enumerated in (1.2), as discussed in the next section. Although the description of Part (3), "explaining of the teaching," seems not to be presented explicitly, the remaining annotation could be said to correspond to it. 


\section{Flow Presented by the Don bsdus}

As mentioned above, the annotation of the $M S A$ from Chapter II onward can be said to accord with the flow explained in (1.2). The k. 2 of Chapter I, to which (1.2) is related, features five similes that correspond to the whole treatise, as other commentaries show. The outline of (1.2) is as follows:

1.2 perfection of subject matter

482.15 I, k. 2

1.2.1 substance of the Mahāyāna:

482.20 (II-IX)

1: skyabs su 'gro ba, 2: rigs, 3: sems bskyed

pa, 4: sgrub pa, 5: de kho na mthong ba, 6:

sems can smin pa, 7: byang chub

1.2.2 practice to carry out the meaning of the Mahāyāna

$482.22(\mathrm{XV}-\mathrm{XIX})$

1.2.2.1 practice to enter the dharma:

$482.24(\mathrm{X}-\mathrm{XIV})$

1: theg pa chen po'i chos la mos pa, 2: thos

pa dang bsam pas chos yongs su 'tshol ba, 3:

gzhan la ston pa, 4: bdag nyid sgrub pa, 5:

gdams ngag thob pa

1.2.2.2 practice to enter the meaning:

483.2

1: thun mong gi ngo bo thabs dang ldan pa' $i$

las, 2: pha rol tu phyin pa'i spyod pa, 3: byang

chub kyi phyogs dang mthun pa'i spyod pa

1.2.2.3 dharma of virtues those who practice must have

483.18

1: rang dang gzhan gyi don phun sum tshogs

pa, 2: chos dang don phun sum tshogs pa, 3:

gang zag gi rang bzhin phun sum tshogs pa

1.2.3 result acquired by practice

$484.11(\mathrm{XX}-\mathrm{XXI})$

1: gnas skabs kyi 'bras bu, 2: thar thug kyi

'bras bu

In (1.2.1), seven topics are enumerated as the substance of the Mahāyāna (theg pa chen po'i rang bzhin). These seven almost correspond to chapter names of the MSA: II: skyabs su 'gro ba (śaranagamana); III: rigs (gotra); IV: sems bskyed pa (cittotpāda); V: sgrub pa (pratipatti); VI: de kho na nyid (tattva); VIII: yongs su smin pa (paripāka); and IX: 
byang chub (bodhi). Chapter VII, mthu (prabhāva), is missing, however.

In fact, the Don bsdud also relates these topics to chapters. For example, (1.2.1.6), sems can smin pa, is divided into three: a method, an agent, and an object. The first corresponds to Chapter VII, and the latter two to the Chapter VIII. Similarly (1.2.2.1) corresponds to Chapters X-XIV. Although (1.2.2.2) and (1.2.2.3) do not have such a straightforward correspondence with chapters, each topic seems to be found in the subdivisions of Chapters XV-XIX. Last (1.2.3) corresponds to Chapters XX-XXI.

As mentioned above, the topics enumerated here does not necessarily accord with the chapter names. The Don bsdus can be regarded as having been constructed by Blo ldan shes rab in accordance with the topics to teach or to practice, rather than the chapters of the $M S A$ themselves. His interpretation of the structure of the $M S A$ may also be seen that way.

\section{Conclusions}

So far, I have surveyed the Tibetan commentaries now available on the $M S A$, and outlined one of them, mDo sde rgyan gyi don bsdus, written by Blo ldan shes rab.

According to his commentary, the $M S A$ originally had a sequence of the topics to teach, to learn, or to practice, and the structure of the $M S A$ is based on this sequence. It is as a consequence of this same structure that the $M S A$ has a multilayered structure.

Of course, this interpretation is not necessarily the same as the original "intention" of the $M S A$, but it seems quite reasonable to argue that there is a particular sequence of topics to the $M S A$, on the basis of which it has been constructed.

I would like to proceed to an examination of the relationship of this structure to that of the Bodhisattvabhümi, in line with this interpratation, and to compare mDo sde rgyan gyi don bsdus with other Tibetan commentaries.

1) See Hakamaya and Arai (1993).

2 ) Sylvain Lévi, Hakuju Ui and Osamu Hayashima points these out. See Hakamaya and Arai (1993) for the bibliography. As for the last, see Naito (2009).

3 ) See also the two commentaries left only in Tibetan translation, *A Aiślokadvayavyākhyāna and * Sūtrālamkārapinḍ̄artha.

4 ) These are contained in the $b K a$ 'gdams gsung 'bum, vols. 1,7 (2), 18, 22, 25, 29, 50, 60, 61. See bKa' gdams dkar chag vols. 1-3 and Kanō $(2007,2009)$ for details.

5 ) As for the brief descriptions on bKa'gdams gsung 'bum and Blo ldan shes rab, see Kanō (2007) and so on. 
6) All quotations are translated by the author.

7 ) Although synopses ( $s a$ bcas) are presented by the editors in Don bsdus (2006, 2009), neither is appropriate for the structure of the Don bsdus.

8 ) Käpadeśa is often described as having seven kinds, but in fact it is composed of eight interrogatives of seven cases and kati (how many), as the commentaries say.

9 ) These four divisions correspond to those found in the Indian commentaries: abhidheya, prayojana, prayojanaprayojana and sambandha. This formula on the necessary elements for the treatise often appears in many Buddhist and non-Buddhist texts, with some variations.

\section{〈Texts and Abbreviations〉}

Don bsdus (mDo sde rgyan gyi don bsdus) (2006): bkha'gdams gsung 'bum. Vol. 1, pp. 203-252.

Don bsdus (2009): rNgog lo tsa'ba Blo ldan shes rab kyis gsung 'bum. Vol. 3. Beijing, 2009, pp. 478544.

bKa'gdams dkar chag: Kha'gdams pa'i gsung 'bum phyogs sgrig thengs dang polgnyis pa/gsum pa'i dkar chag. 3 vols. Chengdu, 2006, 2007, 2009.

bKa'gdams gsung 'bum: Kha' gdams pa'i gsung 'bum phyogs bsgrig. 90 vols. Chengdu, 2006, 2007, 2009.

Tho yig: dPe rgyun dkon pa 'ga'zhig gi tho yig, ed. A khu rin po che, in Materials for a History of Tibetan Literature. Part 3. Śata-pițaka Series, vol. 30. New Delhi, 1963. Rep., Kyoto, 1981.

\section{〈Bibliography〉}

Hakamaya Noriaki 袴谷憲昭, and Arai Hiroaki 荒井裕明. 1993. Daijō shōgon kyōron 大乗荘撖経論. Shin kokuyaku daizōkyō 新国訳大蔵経, Yuga, Yuishiki-bu 瑜伽・唯識部 12. Tokyo: Daizō Shuppan.

Kanō Kazuo 加納和雄. 2007. “Goku-Rodenshērapu cho Shokan, Kanro no Shizuku: Kōtei tekusuto to naiyō gaikan” ゴク・ロデンシェーラプ著『書簡・甘露の滴』: 校訂テクストと内容概観 [rNgog Blo ldan shes rab's sPring yig bdud rtsi'i thig le: Critical edition]. Mikkyō Bunka Kenky $\bar{u}-$ jo kiyo 密教文化研究所紀要 20, pp. 162-105.

—. 2009. “Goku-Rodenshērapu cho Shokan, Kanro no Shizuku: Yakuchū-hen” ゴク・ロデン シェーラプ著『書簡・甘露の滴』: 訳注篇 [rNgog Blo ldan shes rab's sPring yig bdud rtsi'i thig le: Annotated translation]. Mikkyō Bunka Kenkyūjo kiyō 密教文化研究所紀要 22, pp. 196139.

Naitō Shōbun 内藤正文. 2009. “Daijō shōgon kyōron no kōsei to dai 9 shō 'Bodai no shō' no kōzō: Uddāna $(10, k .1)$ no rikai o fumaete”『大乗荘厳経論』の構成と第 9 章「菩提の章」の構造: ウッダーナ $(10, \mathrm{k} .1)$ の理解を踏まえて [The organization of the Mahāyānasūtrālamkkāra and the structure of its chapter IX, "Examination of enlightenment": On the basis of an understanding of an Uddāna Verse (MSA X. 1)]. Indogaku Chibettogaku kenkyūインド学チベット学研究 13. pp. 1-38.

Odani Nobuchiyo 小谷信千代. 1984. Daijō shōgon kyōron no kenkyū 大乗荘㛜経論の研究. Kyoto: 
Bun'eidō Shoten.

〈Key words〉 Mahāyānasūtrālamkāara, rNgog Blo ldan shes rab

(Research Associate, Research Institute for Languages and Cultures of Asia and Africa,

Tokyo University of Foreign Studies) 